"Investigating environmental management accounting in the chemical industry in South Africa"

\begin{tabular}{|c|c|c|}
\hline AUTHORS & \multicolumn{2}{|l|}{$\begin{array}{l}\text { Anet Magdalena Smit } \\
\text { Eddie Kotzee }\end{array}$} \\
\hline ARTICLE INFO & \multicolumn{2}{|c|}{$\begin{array}{l}\text { Anet Magdalena Smit and Eddie Kotzee (2016). Investigating environmental } \\
\text { management accounting in the chemical industry in South Africa. Investment } \\
\text { Management and Financial Innovations, 13(1-1), 151-160. } \\
\text { doi:10.21511/imfi.13(1-1).2016.02 }\end{array}$} \\
\hline DOI & \multicolumn{2}{|c|}{ http://dx.doi.org/10.21511/imfi.13(1-1).2016.02 } \\
\hline RELEASED ON & \multicolumn{2}{|l|}{ Friday, 08 April 2016} \\
\hline JOURNAL & \multicolumn{2}{|c|}{ "Investment Management and Financial Innovations" } \\
\hline FOUNDER & \multicolumn{2}{|c|}{ LLC "Consulting Publishing Company "Business Perspectives" } \\
\hline & & $\begin{array}{l}\text { ニ̃z } \\
\text { ニz:- }\end{array}$ \\
\hline NUMBER OF REFERENCES & NUMBER OF FIGURES & NUMBER OF TABLES \\
\hline 0 & 0 & 0 \\
\hline
\end{tabular}

(C) The author(s) 2022. This publication is an open access article. 
Anet Magdalena Smit (South Africa), Eddie Kotzee (South Africa)

\title{
Investigating environmental management accounting in the chemical industry in South Africa
}

\begin{abstract}
Environmental issues are of increasing concern to a variety of stakeholders in most countries all around the world. There is a growing consensus that conventional accounting practices simply do not provide adequate information to support decision-making in order to manage the environment. Environmental management accounting (EMA) is a combined approach that provides for the transition of data from financial accounting, cost accounting and mass balances to increase material efficiency, reduce environmental impacts and risks and, ultimately, lead to the reduction of environmental costs. This paper investigates the practise of EMA in the chemical industry. A questionnaire was administrated to a selected group of participants who are employees in the chemical industry in South Africa. Different functional roles from different types of chemical companies were identified to participate. The findings of this paper indicate that there is a good level of awareness of EMA in the South African chemical industry. Most organizations are applying sound environmental practices and are adopting environmental strategies and tools to improve their current status. Different levels of awareness exist between the different functional roles in the respective organizations. Operational and capital environmental information are disclosed and organizations do generate and record information on physical and monetary environmental management accounting.
\end{abstract}

Keywords: environmental management accounting, chemical industry, environmental practices, environmental management systems.

JEL Classification: M410, Q, P28.

\section{Introduction}

The global profile of environmental issues has significantly risen during the past two decades and has been advanced by two recent major incidents: the Gulf oil spill (April, 2010) and the Fukushima radiation leak in March, 2011. According to Winston (2011), these events received worldwide media attention and concerns have escalated over major issues such as global warming, depletion of non-renewable resources and the loss of natural habitats. Frequently, these disasters are related to poor industrial oversight and, unfortunately, in both these cases all evidence led to man-made failures. Because of these incidents and in recognition that our current way of life poses a threat to us and our planet, various global agreements have been signed to prevent possible future environmental damages. Some of these agreements are: The Kyoto Protocol for Greenhouse Gas Emissions, the World Summit on Sustainable Development held in Johannesburg, South Africa, in 2002, the United Nations Change Conference held in Copenhagen, in December 2009, and most recently, the $21^{\text {st }}$ Session of the Conference of the Parties to the United Nations Framework Convention on Climate Change (COP21/CMP11) hosted in Paris during December 2015. These conventions are an indication of the concern that stakeholders have

(c) Anet Magdalena Smit, Eddie Kotzee, 2016.

Prof. Anet Magdalena Smit, Associate Professor (Ph.D.), North-West University, NWU Potchefstroom Business School, Potchefstroom, South Africa.

Mr. Eddie Kotzee, MBA Student at NWU Potchefstroom Business School, South Africa. about the negative impact industries have on the environment and humans.

The growing importance of environmental and social issues has put some pressure on companies to implement environmental and social systems (Laurinkevičiūtè, Kinderytė and Stasiškienè, 2008). The real challenge for all organizations is to identify and find ways to reduce their impact on the environment in a sustainable manner. Stakeholders, such as customers and shareholders, increasingly want to see that businesses are actively reducing environmental risks and the impact thereof before continuing to offer support (Savage and Jasch, 2005). Nearly all aspects of business are affected by environmental pressures, including accounting. From an accounting perspective the initial pressures were felt in external reporting, including environmental disclosures in financial reports and/or the production of separate environmental reports. However, environmental issues cannot be dealt with solely through external reporting. Environmental issues need to be managed before they can be reported on and this requires changes to management accounting systems. This is where the need for an efficient way of managing and reporting of environmental costs becomes crucial and where environmental management accounting could play a role. Jasch (2006) confirms that the main problem with environmental management accounting (EMA) is that it lacks a standard definition for environmental costs. It, further, states that many managers are unaware of specific environmental costs, have no information with which to manage them and have no incentive to reduce them. 
It must be emphasized that many management accounting techniques significantly underestimate the cost of poor environmental behavior. On the other hand, many overestimate the cost and underestimate the benefits of improving environmental practices. Some organizations are even unaware of the impact that environmentalrelated activities can have on the profit and loss accounts and the balance sheet. They miss out on identifying cost reduction and other improvement opportunities.

\section{Background of the study}

The encyclopaedia Britannica defines the chemical industry as a complex combination of processes, operations and organizations that is engaged in the manufacturing of chemicals and its derivatives. Because of the complexity of the manufacturing processes, many of the products are potentially very hazardous at certain stages. These processes often require high temperatures, high pressures and reactions which can be dangerous unless carefully controlled. Raw materials are converted to finished goods, and certain by-products like carbon monoxide, effluent and solid waste are generated. These are the harmful products that are most often seen as pollutants and should be managed. However, many organizations do struggle to measure and contain these harmful by-products (Clements et al., 2010).

According to Burrit, Schaltegger and Zvezdov (2013), the interest in sustainability and its implications for organizations has increased steadily since the issue first became topical two decades ago. It is increasingly recognized that sustainability not only poses ethical issues but also has a direct consequence for economic performance. More and more companies are being pressurized to act responsible on environmental factors. Stricter environmental legislation and regulation imposes a compliance burden, and organizations are forced to monitor activities and outputs even more closely (Burrit and Christ, 2013). Although EMA is not mandatory in South Africa at this stage, nor for private or public firms, the increasingly stringent environmental regulations have prompted firms to pay more attention to environmental issues. The consequences of poor environmental behavior may have a real adverse impact on a business and its finances. Some actual examples are huge fines, destruction of brand values, loss in sales, inability to secure finance, loss of insurance cover, law suits and damage to corporate image.

\section{Problem statement}

Research indicates that many organizations do not identify and separate environmental costs adequately.
They have a definite lack of awareness and understanding of the magnitude of the environmental costs generated and, hence, proper environmental management is lost in the process (UNDSD, 2001). There is often a divergence between environmental management and financial management. Financial managers often do not appreciate the risks and financial implications associated with poor or reactive environmental management while environmental managers do not always fully appreciate the economic imperatives that determine the viability of a corporation (Ambe, 2007). Also, many organizations have conventional accounting systems that allocate environmental costs to general overhead accounts. This often results in environmental costs being kept from the attention of management (Ambe, 2007). More than often opportunities for cost savings are lost because organizations do not understand the magnitude of environmental costs. The advantage of environmental accounting is the ability to determine and create awareness regarding costs related to the environment. It also helps to identify techniques for reducing and avoiding related environmental costs (Farouk, Cherian and Jacobs, 2012).

\section{Objective and methodology}

The primary objective of this paper was to investigate the practices of EMA in the South African chemical industry. The study evaluated the current EMA practices that do exist in the chemical industry as well as how effective the principles of EMA are incorporated into their conventional accounting systems. This research consists of two phases, namely, literature and an empirical study. The purpose of the literature review was to gain valuable insight into sustainable development, the South African chemical industry and EMA. Very few studies related to EMA have been done in the chemical industry. A survey questionnaire was designed and distributed to selected participants. It is a modified questionnaire and adopted from Ambe (2007), where the main objective was to indicate a South African perspective on the theory and practice of EMA. The survey questionnaire was specifically distributed to production personnel, environmental and accounting practitioners in the different sections of the chemical industry. The number of questionnaires distributed to participants in the chemical industry were 150 and 77 were completed and returned. This results in a response rate of $51 \%$.

\section{EMA and the chemical industry}

4.1. Environmental management systems. Due to sustainable growth and development, organizations 
around the world, as well as their shareholders, are increasingly becoming aware of the need for environmental management and social responsible behavior. The United States Environmental Protection Agency (USEPA, 2014) defines an environmental management system as a framework that helps a company to achieve its environmental goals through consistent control of its operations. The assumption is that this type of framework will improve the environmental performance of a company in general. The USEPA further states that the environmental management system does not dictate the level of environmental performance that must be achieved. The environmental management system rather assists a company to address its regulatory demands in a systematically and costeffective manner. According to Ambe (2007), organizations that have implemented an environmental management system are more likely to embrace new environmental technologies and are more aware of the environmental impacts of their activities than those organizations that did not implement an environmental management system.

With regards to the concept of environmental management systems many organizations are considering the International Organization for Standardization (ISO) standards to provide a framework that will ensure alignment and consistency, both nationally and internationally. ISO 14004 specifies detailed criteria for an environment management system. It, basically, maps out a framework that a company can follow to set up an effective environmental management system. Using these standards can provide assurance to all stakeholders that the environmental impact is being measured and improved. If applied accordingly, an organization can reduce cost of waste management and save on consumption of energy and materials (Živković, S., Takić, L. and Živković, N., 2013). The entire ISO 14000 family of standards provides management tools for organizations to manage their environment aspects and to assess their environmental performance.

4.2. Chemical industry. According to Clements et al. (2010), the chemical industry uses a wide range of raw materials to create an immense variety of products, which impinge on virtually every aspect of our lives. Interestingly, while many of these products (paints, plastics, soaps and more) are purchased by consumers directly, a majority of chemicals manufactured are used to make products for other industries, including other branches of the chemical industry itself. Many new ideas and concepts have surfaced the industry satisfying the increasingly sophisticated, demanding and environmentally-conscious consumers (Clements et al., 2010). According to the Chemical and Allied
Industries' Association (CAIA, 2014), the chemical industry in South Africa is the largest of its kind in Africa. It is highly complex and widely diversified, with end products often being composed of a number of chemicals which have been combined in some way to provide the required properties and characteristics. It can be divided into four broad categories, namely, Base chemicals, Intermediate chemicals, Chemical end-products, and Speciality end-products.

South Africa's chemical industry is of substantial significance to the South African economy and a key component of the country's industrial base. According to Statistics SA (2014), petroleum, chemical products, rubber and plastic products contributed R421 million to the GDP in 2013, which is about $25.1 \%$ of total manufacturing sales. However, the industry also has a very distinctive negative image when it comes to pollution. According to the 2012 report of the World's Worst Pollution Problems, the chemical industry is listed as one of the top 10 polluters. The report states that chemical manufacturing is a large source of pollution worldwide and can be directly tied to close to 200 of the polluted sites in the Blacksmith Institute database (Blacksmith, 2012). Potentially, this is putting approximately 5.3 million people at risk of exposure.

Clements et al. (2010) explain that chemical manufacturers around the globe try to generate as little waste as possible, mainly through reaction choice, process design and recycling. The industry aims to use chemical reactions and processes that make the most effective use of available resources and generate the smallest possible amount of waste material.

As part of plant operations material balances are used as the basis to measure unit performance. It is a very useful tool to check the actual plant performance against the original design and engineers are using material balances on a daily basis to do trouble shooting, to improve plant efficiencies and to reduce environmental discharges (Coulson and Richardson, 2007).

4.3. Environmental management accounting. Over the past years EMA has formed part of an increased literature search and approach that is helping organizations to use accounting information for environmental sensitive internal decisionmaking (Kurniati, Rahadi and Danial, 2010). Damages and disturbances to the original state of the environment are unavoidable and will require sound decision-making processes informed by credible data. EMA principles, tools and new methods designed by researchers and practitioners 
can be used to generate information, containing economic as well as environmental sensitive costs, and support management to enable environmentallysensitive decision-making (Debnath, Bose and Dhalla, 2012).

According to Burrit et al. (2013), EMA provides a pragmatic response to criticism that conventional management accounting has failed in its ability to provide explicit consideration of environmental issues. Environmental costs are, frequently, hidden in the general overhead accounts and potential benefits are often downplayed or ignored. By providing data on the physical and financial elements of environmental performance, it has been suggested that EMA will provide the information that can be used by managers to assess opportunities for economic and environmental improvement (Gale, 2006).

\subsection{Physical environmental management} accounting. Internal management accounting focuses on physical resources and monetary resources. The first part of EMA, namely, the tracking of physical information, is a very important tool in environmental accounting as it allows the company to analyze and manage their environmental performance (Savage et al., 2005). Information such as energy usage, water consumption and quantity of waste is an example of physical information that could be analyzed and reported on. Unfortunately, the physical accounting information is not always easily available to accounting personnel. Personnel in areas, such as production or in the environmental section will have more detailed information and, therefore, accountants need to work more closely with them in order to improve accuracy of physical EMA information.

The physical categories described are in line with the standard practice of mass balancing and the general structure of ISO 14031 for environmental performance indicators for operational systems. However, these physical categories may be adjusted as needed to suit specific sectors or individual organizations. Environmental performance indicators can assist organizations to assess and report the material-related aspects of its environmental performance (Henri and Journeault, 2008).

4.5. Monetary environmental management accounting. Monetary EMA is accounting that focusses on the financial impact it has on environmental performance (Savage et al., 2005). It allows management to make a better evaluation of the monetary aspects of products. However, different companies view environmental costs differently, depending on the company's view on environmental matters such as economic and environmental goals (Ambe, 2007).

All expenditures for environmental protection, such as expenditures to prevent, control or reduce waste as well as disposal, clean-up and treatment for environmental related aspects, form part of environmental expenditure. To ensure that EMA is accurate and consistent, physical inputs and outputs must be linked with their appropriate cost categories. If environmental costs are linked to their specific cost categories, it could enable management to effectively identify and manage environmental costs (Savage et al., 2005).

\section{Results and discussion}

5.1. Data analysis. The data collected were analyzed through statistical and practical analysis methods by the Statistical Consultation Services of North-West University. These analytical methods were valuable to investigate the validity of the questionnaire and to evaluate the awareness of EMA in the South African chemical industry. The data collected from the questionnaire were reliable with Cronbach's Alpha values on questions ranging from 0.68 to a maximum of 0.90 .

5.2. Results. The questionnaire was divided into four sections. The first section was to gather some information about the characteristics of the respondents and the organizations that they present. The rest of the questionnaire consists out of the other three sections, namely, current and future environmental issues, the information in the sustainability reports and, lastly, the presentation of the physical and monetary information.

5.3. Section 1: organizational characteristics. The majority of the respondents in this study were from private $(76.6 \%)$ organizations. Only a small percentage of the participants were from a Joint Venture (2.6\%) and none were from a Close Corporation. It indicates that many of the chemical organizations in South Africa are owned by the Private sector (76.6\%). Some participants were also from Public listed organizations (20.8\%).

The majority of the participants were employed by organizations with an annual turnover of more than R1 billion (75.3\%). The proportional split in percentages between organizations with approximate annual turnovers of R50-R500 million was 9.1\% and for R500 million-R1 billion was 5.2\%.

The data indicate a spread of very small to very large chemical organizations in South Africa. The proportional percentages in terms of employees employed, according to the responses, were as follows: less than 100 employees $(2.6 \%), 101-500$ (49.4\%), 501-1000 (10.4\%), 1001-5000 (11.7\%) and 
more than 5000 employees (24.7\%). Almost half of the respondents $(49.4 \%)$ were employed by medium size organizations (101-500).

Most respondents were from the polymers $(41.6 \%)$ and petro-chemical (35.1\%) industries. A small percentage of respondents resides in the agri- $(6.5 \%)$ and speciality $(16.9 \%)$ chemicals industries.

The purpose of the study was to focus on a certain level of knowledge, skills and decision making abilities of the respondents. In this context environmental practitioners, managers in production and financial practitioners were requested to complete the questionnaire. The results obtained indicated a suitable spread of different participants in the different functional roles. The proportionate percentage split obtained was environmental practitioners at $22.1 \%$, financial practitioners at $36.4 \%$ and production personal at $40.3 \%$.

\subsection{Section 2: current and future environmental} issues. The first part of Section 2 deals with questions (Yes or No answers) related towards the organizational strategies and tools employed in the organization to manage the environment. Based on results, $100 \%$ of respondents indicated that their organization does have an environmental policy, does have environmental goals and targets and does have an environmental management system in place. A small percentage $(2.6 \%)$ of respondents indicated that their organization did not have an environmental improvement plan and that they were not ISO 14001 certified. A large portion also indicated that they adhered to the South Africa Bureau of Standards (SABS).

In Section two, the second part, the respondents have to identify the drivers that urge their organization to implement an Environmental Management System. A 5 point Lickert scale was used where 1 was extremely low and 5 extremely high. The respondents have rated compliance with regulation as the most important driver for the organization's environmental management system. More than half of the respondents $(43,55.8 \%)$ have rated it as extremely high with a mean of 4.5 and a standard deviation of 0.53 . The driver, certification of an international standard, was rated as the second highest driver. Thirty-four respondents have rated it as extremely high (44.2\%) with a mean of 4.3 . Twenty-one respondents have rated corporate citizenship as the third highest driver for their organisation's environmental management system with a mean of 4.1 .

In Section two, part three, the respondents have to rate the level of priority of a few key environmental issues currently employed in their organization on the same Lickert scale. When assessing the different priority levels given to key themes of environmental information requirements the key theme that was rated as the highest priority, was employee health $(90.9 \%)$ with a mean of 4.4 , followed by environmental liability $(87.0 \%)$ with a mean of 4.2. In the third position as a current priority was emission from plants $(85.7 \%)$ with a mean of 4.2. An environmental improvement plan (83.1\%) which implies a focus for continuous improvement had a mean of 4.1. The key theme that had the lowest priority was carbon taxes $(32.5 \%)$ with a mean of 3.2 with a relative high standard deviation of 0.88 .

In Section two, part four, the respondents have to rate a few key environmental issues that they regard as important for the future of the business. According to the results obtained, the future environmental issue with the highest importance was waste water management $(89.6 \%)$ with a mean of 4.2 and a standard deviation of 0.63 . Hazardous waste (88.4\%) was also identified as of high importance with a mean of 4.1. The least important environmental issues were non-hazardous waste management (62.4\%) with a mean of 3.8 and surface water use and management thereof $(59.8 \%)$ with a mean of 3.7 .

A practical significance is seen between the different types of chemical industries when assessing the effect sizes. The petro-chemical industry has rated a higher effect size (1.15) than the polymer and agri-chemical industries with regards to the importance of current environmental key themes. The petro-chemical industry has also rated the future importance of environmental issues higher than the polymer and speciality-chemicals industries with an effect size of 1.04.

Table 1. The effect sizes of environmental issues between different chemical industries

\begin{tabular}{|c|c|c|c|c|c|c|}
\hline & & \multirow[b]{2}{*}{$\mathrm{N}$} & \multirow[b]{2}{*}{ Mean } & \multirow[b]{2}{*}{ Std. deviation } & \multicolumn{2}{|c|}{ Effect sizes } \\
\hline \multicolumn{2}{|c|}{ Environmental Issues } & & & & Polvmers and: & Petro-chemical \\
\hline \multirow{3}{*}{$\begin{array}{l}\text { Q9 Factor } \\
\text { Current environmental issues }\end{array}$} & Polymers & 32 & 3.91 & 0.39 & & \\
\hline & Petro-chemical & 27 & 4.49 & 0.51 & 1.15 & \\
\hline & Speciality & 13 & 3.76 & 0.72 & 0.21 & 1.02 \\
\hline
\end{tabular}


Table 1 (cont.). The effect sizes of environmental issues between different chemical industries

\begin{tabular}{|c|c|c|c|c|c|c|}
\hline \multirow{2}{*}{\multicolumn{2}{|c|}{ Environmental Issues }} & \multirow{3}{*}{$\begin{array}{l}N \\
32 \\
\end{array}$} & \multirow{3}{*}{$\begin{array}{l}\text { Mean } \\
3.83\end{array}$} & \multirow{3}{*}{$\begin{array}{c}\text { Std. deviation } \\
0.46\end{array}$} & \multicolumn{2}{|c|}{ Effect sizes } \\
\hline & & & & & \multirow{2}{*}{ Polymers and: } & \multirow{2}{*}{$\begin{array}{l}\text { Petro-chemical } \\
\text { and: }\end{array}$} \\
\hline \multirow{4}{*}{$\begin{array}{l}\text { Q10 Factor } \\
\text { Future environmental issues }\end{array}$} & Polymers & & & & & \\
\hline & Petro-chemical & 27 & 4.31 & 0.46 & 1.04 & \\
\hline & Speciality & 13 & 3.92 & 0.41 & 0.20 & 0.85 \\
\hline & Total & 72 & 4.03 & 0.50 & & \\
\hline
\end{tabular}

5.5. Section 3: information in sustainability reports. This Section is divided into 3 parts. The first part deals with certain items that organizations disclose in their annual or sustainability reports. Part 2 of the Section deals with operating expenditures and part 3 with capital expenditures.

In Section 3, part 1, the respondents have to indicate by selecting Yes or No whether certain items are disclosed or not disclosed in their statements. According to the results, $70(90.9 \%)$ respondents answered a yes to disclosing environmental key performance indicators in their annual report and 69 (89.6\%) respondents answered a yes towards disclosing environmental objectives in their annual report. All the other questions received a yes response of more than $70 \%$ except for financial environmental information (63.6\%), 26 of the respondents indicated a no $(36.4 \%)$ to financial environmental information not being disclosed.

Section 3, part 2 deals with operating expenditures. Operational expenditure for any organization is the ongoing cost for running the business. This is the money the business spends in order to turn inventory into throughput. Once again, the five point Lickert scale was used and respondents have to identify which of the operating expenditures were regarded as very important (5) to the least important (1).

Solid waste treatment at $63.7 \%$ with a mean of 3.8 was rated as the most important, pollution prevention at $62.4 \%$ with a mean of 3.7 was rated in second place, followed by liquid effluent treatment at $58.5 \%$ with a mean of 3.6. In the fourth and last place was waste gas and air treatment at $57.2 \%$ with a mean of 3.55. A small percentage $(<6 \%)$ of participants did not rate some of the sub-questions which might indicate that they are not familiar with the concept of operating environmental expenditure or with the issues underlined.

In section 3, part 3, the respondents have to rate the importance of capital expenditures. Capital expenditure is used by an organization to acquire, or upgrade physical assets. In more simple terms, it can be explained as money used to improve an existing piece of equipment or asset.

Equipment improvement was rated the highest at $63.6 \%$ with a mean of 3.7 , followed by pollution prevention at $58.5 \%$ with a mean of 3.6 and solid waste treatment at $58.4 \%$ with a mean of 3.55 . Research and development at $57.2 \%$ with a mean of 3.5 was rated in the fourth place, followed by waste gas and air treatment at $55.9 \%$ with a mean of 3.4 and liquid effluent treatment was rated at $48.1 \%$. Again, a small percentage $(<6 \%)$ of participants did not rate some of the sub-questions which might indicate that they are not familiar with the concept of capital environmental expenditure or with the issues underlined.

Table 2 indicates the effect sizes between the different functional roles of the respondents based on the disclosure of environmental expenditure. Environmental practitioners and production personel have rated disclosure of operational and capital environmental expenditures lower as financial practitioners.

Table 2. Effect sizes between different functional roles on the disclosure of environmental expenditure

\begin{tabular}{|c|c|c|c|c|c|c|}
\hline \multirow{2}{*}{\multicolumn{2}{|c|}{ Disclosure of operating and capital expenditure }} & \multirow{2}{*}{ N } & \multirow{2}{*}{ Mean } & \multirow{2}{*}{ Std. deviation } & \multicolumn{2}{|c|}{ Effect sizes } \\
\hline & & & & & Environmental and: & Financial and: \\
\hline \multirow{4}{*}{ Q13 Factor } & Environmental & 17 & 3.57 & 0.65 & & \\
\hline & Financial & 28 & 3.81 & 0.75 & 0.32 & \\
\hline & Production & 31 & 3.60 & 0.75 & 0.04 & 0.28 \\
\hline & Total & 76 & 3.67 & 0.73 & & \\
\hline
\end{tabular}

5.6. Section 4: physical and monetary information. Section 4 deals with the physical (part 1) and monetary information (part 2) of EMA in the organization. Physical information refers to information such as raw and auxiliary materials, operating materials, water, energy, solid waste, hazardous waste, waste water and air emissions that are generated and reported on in some or other unit of measurement.

Figure 1 below reflects the rating on physical environmental accounting information from the respective respondents. It was noticed that all the 
responses were above $70 \%$. According to the results hazardous waste $(81.9 \%$ with a mean of 4.2 and standard deviation of 0.77 ) was indicated as the most likely element to be generated, measured and recorded. This was followed by water and energy, both with a percentage of $80.6 \%$.

\section{Percentage Rating (4+5)}

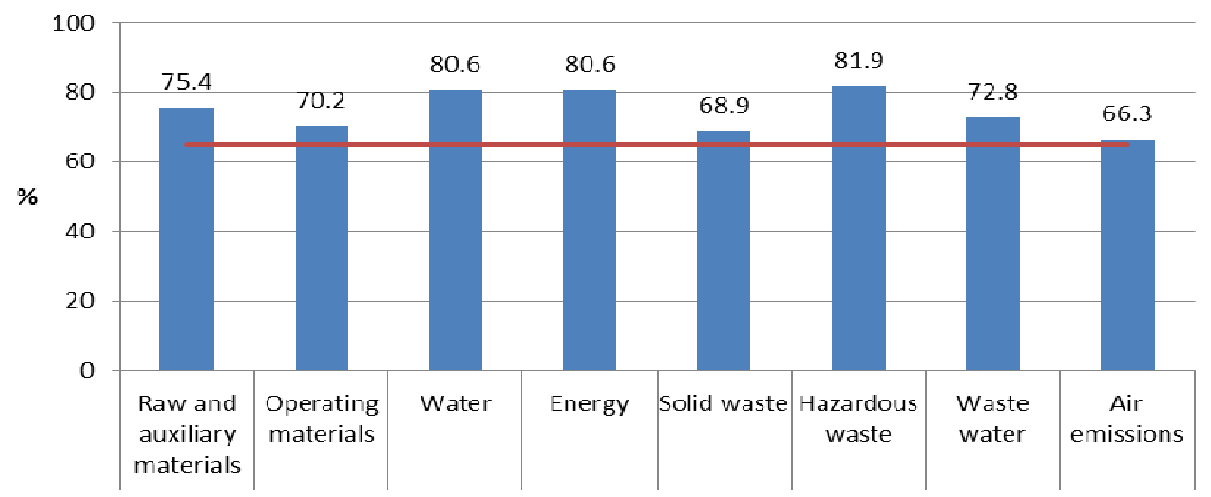

Fig. 1. Combined rating of high and extremely high on physical EMA

The monetary information of EMA refers to information such as cost of product outputs, cost of non-product outputs, waste and emission control costs and prevention costs that will be generated and reported on in Rand value.

Figure 2 reflects that the results for all identified elements were greater than $60 \%$. According to the responses, cost of product outputs (mean of 4.2) was indicated as the most likely element to be generated and recorded. Respondents rated prevention and other environmental management cost $(61.1 \%)$ as the least likely element to be generated and recorded as part of monetary environmental information.

\section{Percentage Rating (4+5)}

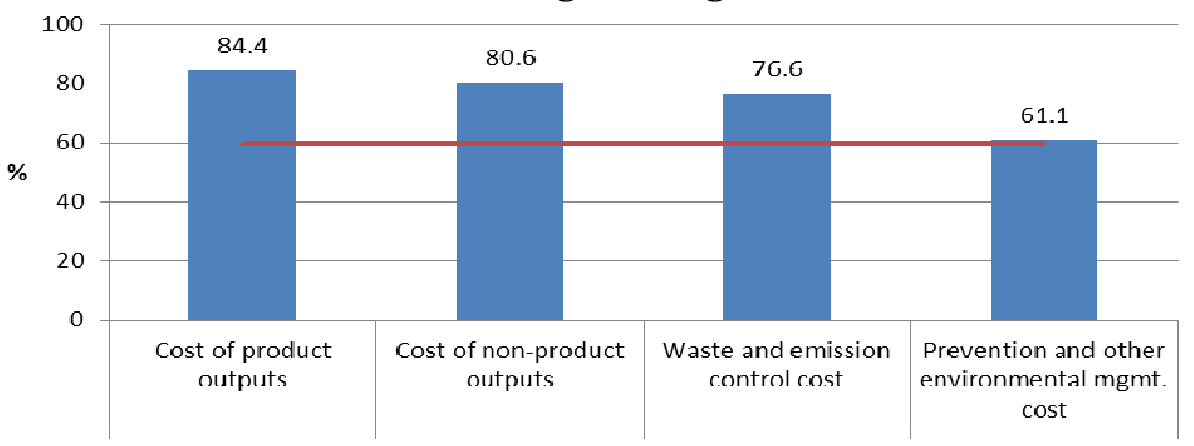

Fig. 2. Combined rating of high and extremely high on monetary EMA

Table 3 indicates the effect sizes between the different functional roles of the respondents based on the generation and recording of physical and monetary environmental information. There is almost no significant difference between the different functional roles on the generation and recording of physical environmental information. However, on the generation and recording of monetary environmental information there is a small difference between environmental and the other two functional groups.

Table 3. Effect sizes between different functions on physical and monetary environmental information

\begin{tabular}{|c|c|c|c|c|c|c|}
\hline \multirow{2}{*}{\multicolumn{2}{|c|}{$\begin{array}{l}\text { Generate and record physical and monetary environmental } \\
\text { information }\end{array}$}} & \multirow{3}{*}{$\begin{array}{l}\text { N } \\
17\end{array}$} & \multirow{3}{*}{$\begin{array}{l}\text { Mean } \\
4.01\end{array}$} & \multirow{3}{*}{$\begin{array}{c}\text { Std. deviation } \\
0.64\end{array}$} & \multicolumn{2}{|c|}{ Effect sizes } \\
\hline & & & & & \multirow{2}{*}{$\begin{array}{l}\text { Environmental } \\
\text { and: }\end{array}$} & \multirow{2}{*}{ Financial and: } \\
\hline \multirow{4}{*}{$\begin{array}{l}\text { Q15 Factor } \\
\text { Physical information }\end{array}$} & Environmental & & & & & \\
\hline & Financial & 28 & 4.05 & 0.64 & 0.05 & \\
\hline & Production & 31 & 3.99 & 0.63 & 0.04 & 0.09 \\
\hline & Total & 76 & 4.02 & 0.63 & & \\
\hline \multirow{4}{*}{$\begin{array}{l}\text { Q16 Factor } \\
\text { Monetary information }\end{array}$} & Environmental & 17 & 3.81 & 0.65 & & \\
\hline & Financial & 28 & 4.05 & 0.70 & 0.35 & \\
\hline & Production & 31 & 4.01 & 0.52 & 0.30 & 0.06 \\
\hline & Total & 76 & 3.98 & 0.62 & & \\
\hline
\end{tabular}




\section{Conclusions}

Environmental practices. The level of awareness regarding environmental practices amongst all participants was very high and the responses indicated that every respondent was aware of the existence of key environmental aspects. All of the respondents indicated that their respective organizations do have the necessary environmental strategies and tools in place. All organizations do have an environmental policy, have established an environmental management system and do have environmental goals and targets in place. It seems that all chemical organizations do have a very good environmental strategic intend. Only a few respondents indicated that their organizations do not have an environmental improvement plan and that their organization is not ISO 14001 certified.

These results indicate that environmental practises are not a new phenomenon and organizations in the chemical industry have established systems in place. Some of the organizations use international auditing bodies but some are using local certified institutions. This might be due to the fact that some of the organizations have a global footprint and certification requirements are standardized across businesses in the same organization. Interesting is that none of the organizations utilizes the South African Bureau of Standards (SABS) as a certifying body, although many of the SABS standards are applied.

Respondents have rated compliance with regulation as the biggest driver for the organization's environmental management system. It confirms that regulations and legislation are playing a vital role and there is a definite seriousness in driving the organization's environmental management system. This is a pro-active approach that assists in reducing the risk and impact of environmental noncompliances. It also improves the health and safety practises for all employees in the organization.

With regard to the level of priority on current key environmental issues, employee health was rated as highest priority followed by reducing environmental liability and emissions from plants. The priority on carbon taxes as a current issue was rated much lower than the other key themes. This indicates that the well-being of employees is first priority to organizations. However, the priority rating of carbon taxes is a concern. Although carbon taxes are in its early stages of being applied as legislative requirement, the publication of Minimum Emission Standards (MES) in March 2010, promulgated in terms of section 21(3)(a) of the National Environmental Management: Air Quality Act (No.39 of 2004), have placed organizations under pressure to act. Accordingly, companies have to adhere to the act by 1 April 2015 for existing plants, but since then it has been postponed to 2016 (Department of Environmental Affairs, 2016).

Many organizations are already measuring and applying a carbon emission disclosure report. However, despite these actions it remains a concern that organizations are not applying enough effort to reduce carbon emissions.

Waste water management, hazardous waste management and protection of air quality are seen as environmental issues that have high levels of future importance to the organizations. It confirms that organizations are aware of critical environmental issues and have a drive to protect their immediate environment and satisfy stakeholder needs. The fact that most of the future environmental issues were rated as of high importance is a positive sign, but the essence lies within execution of improvement plans to address and improve the management and impact thereof.

The petro-chemical industry is applying a higher level of priority on environmental practices as their fellow chemical industries. The petro-chemical industry is a very large and profitable industry in South Africa. According to the annual sustainability reports of this specific industry, structured processes are followed to identify environmental-related issues. Internal risk assessments identify these issues whereby capital investments are applied to improve the environmental risk and impact.

Information in sustainability reports. Environmental information that is disclosed in the annual reports contributes towards the awareness of environmental management accounting in the chemical industry. Chemical organizations that are listed on the JSE are required to set environmental objectives and report the status annually to their shareholders and the public. Other information, like environmental impact and risk, initiatives to improve environmental impacts, environmental key performance indicators, qualitative non-financial and financial information and actual incidents or fines should also be reported on.

The majority of respondents indicated that their organizations do disclose many items such as environmental key performance indicators and environmental objectives in their reports. Solid waste treatment and pollution prevention was rated as the highest issues being disclosed. Although both private and public firms responded that they are aware to record and disclose environmental issues, it was evident that the listed firms pay more attention to detail. The reason could be that listed companies are mandatory to publish integrated reports and to 
adhere to the requirements of King 111 in South Africa, which implies an increased emphasis on the environmental and social aspects.

Environmental practitioners and production personnel have rated disclosure of operating and capital environmental expenditures lower than financial practitioners. This indicates that the environmental and production functions are not fully aware of what items get disclosed in the sustainability reports. The challenge would be to establish proper communication channels to ensure that all functions have the same level of environmental information that will inevitably improve integration between the different functions but also improve the level of decision-making in the organization.

Physical environmental management accounting. Chemical organizations continue to generate and record physical environmental information during the production process. Material inputs, product and non-product outputs are measured on a continuous basis to ensure the operations are effectively being operated. Involvement of production staff and environmental practitioners are very critical to assess and evaluate physical information related to environmental management accounting.

Respondents rated hazardous waste, energy and water as the topics that are very high on the generation and recording of physical information per unit. Air emissions are rated as the lowest. It implies that some control measures are in place and environmental performances are managed. This will, ultimately, lead to improved efficiencies. The average rating for the generation and recording of physical environmental information is high. It can be concluded that the level of awareness amongst respondents in the chemical industry for the disclosure of physical information is good.

\footnotetext{
Monetary environmental management accounting. Monetary environmental management accounting focusses on the financial impact of environmental performance. It includes costs such as cost of product and non-product outputs, waste and emissions control costs and prevention costs. Cost of product outputs was rated as the highest compared to the other monetary environmental information. Prevention and other environmental costs have been rated lowest, whilst cost of nonproduct output and waste and emission cost control was rated moderately.
}

Financial practitioners and production personel have rated the generation and recording of monetary environmental information slightly higher as environmental practitioners. There is almost no significant difference between them with a small effect size. Environmental practitioners have rated monetary information lower and the reason might be due to the level of exposure and knowledge regarding the financial information in the organization. Monetary information is more associated with the financial function confirming the theoretical statement that financial practitioners often do not interact with other functions. It seems that there is definitely some interaction in the chemical industry between the financial and production functions.

In general, good levels of understanding and awareness of certain EMA aspects do exist in the South African chemical industry. The awareness regarding strategies and tools are very good and most organizations drive their respective environmental management systems to ensure compliance with regulation. South African chemical organizations are thoughtful about continuous environmental improvement by applying these tools and strategies. The levels of priority regarding certain environmental issues and key themes are high but might change as legislation and regulation changes. Considering the fact that only respondents from the chemical industry participated it is comforting to see that the environmental issue that is rated as highest importance is hazardous waste management and that they are aware of the environmental risks associated with their type of industry. At this stage it is not possible to express an opinion whether the results could be applied to other industries because the emphasis put on specific environmental issues varies from industry to industry.

There is a high level of understanding and awareness regarding physical and monetary EMA. This information is used by chemical organizations to assess opportunities for economic and environmental improvement. There seems to be a small difference in the awareness between the different functions and it is recommended that environmental practitioners get the same exposure in, specifically, the generation and recording of monetary environmental management accounting. This will cause improved levels of environmental cost awareness amongst this function which will stimulate new opportunities to improve the environmental performance of the organization.

\section{References}

1. Ambe, C.M. (2007). Environmental management accounting in South Africa: Status, challenges and implementation framework, Pretoria: Tshwane University of Technology (Thesis - DTECH).

2. Ambe, C.M. (2007). Perspectives on environmental management accounting in South Africa, Southern African Journal of Accountability and Auditing Research, 7, pp. 59-66. 
3. Blacksmith Institute (2012). The World's Worst Pollution Problems: Assessing Health Risks at Hazardous Waste Sites. Available at: http://www.worstpolluted.org/files/FileUpload/files/ 2012\%20WorstPolluted.pdf. Date of access 14 April 2014.

4. Burrit, R.L. and Christ, K.L. (2013). Environmental management accounting: the significance of contingent variables for adoption, Journal of Cleaner Production, 41, pp. 163-173.

5. Burrit, R.L., Schaltegger, S. and Zvezdov, D. (2013). Exploring Corporate Practices in Management Accounting for Sustainability. London: ICAEW Charitable Trusts.

6. Chemical and Allied Industries' Association (CAIA). (2011).Chemical Industry Introduction - an overview as at January 2011. Availiable at: http://www.caia.co.za/index.php?pg=17. Date of access: 30 July 2014.

7. Clements, A., Dunn, M., Firth, V., Hubbard, L., Lazonby, J. and Waddington, D. (2010). The essential chemical industry. York: Chemical Industry Education Centre.

8. Coulson, J.M. and Richardson, J.F. (2007). Chemical engineering Design. $4^{\text {th }}$ ed. Oxford: Butterworth-Heinemann Elsevier.

9. Debnath, S., Bose, S.K. and Dhalla, R.S. (2012). Environmental management accounting: An overview of its methodological development, International Journal of Business Management, 5, pp. 44-57.

10. Department of Environmental Affairs. (2016). Media statement for Minister's announcement of decisions for applications for postponement of compliance timeframes for minimum Air Quality Emission Standards. Availiable at: http://www.environment.gov.za/mediarelease/molewa_airqualityemissionstandards. Date of access: 7 January, 2016.

11. Farouk, S., Cherian, J. and Jacob, J. (2012). Green accounting and management for sustainable manufacturing in developing countries, International Journal of Business and Management, 7 (20), pp. 34-48.

12. Germain, G.L., Arnold, R.M., Rowan, J.R. and Roane, J.R. (1998). Safety, Health, Environment and Quality Management. $2^{\text {nd }}$ Ed. Loganville: International Risk Control America, Inc.

13. Gale, R. (2006). Environmental management as a reflexive modernisation strategy in cleaner production, Journal of Cleaner production, 14, pp. 1228-1236.

14. Henri, J.F. and Journeault, M. (2008). Environmental performance indicators: An empirical study of Canadian manufacturing firms, Journal of Environmental Management, 87, pp. 165-176.

15. IFAC. (2005). International guidance document: Environmental Management Accounting International Federation of Accountants. New York, NY: IFAC.

16. ISO (International Organisation for Standardisation) (2014). About ISO: What are standards? Available at: http://www.iso.org/iso/home/about.htm. Date of access: 12 April 2014.

17. IISD (International Institute for Sustainable Development) (2014). Operational Sustainability. Available at: http://www.iisd.org/about/sdreporting/. Date of access: 12 April 2014.

18. Jasch, C. (2006). How to perform an environmental cost assessment in one day, Journal of Cleaner Production, 14, pp. 1194-1213.

19. Kurniati, E., Rahadi, B. and Danial, M. (2010). Implementing environmental management accounting (EMA) in improving eco-efficiency on corporate activities: Case study on sugarcane company, Journal of Applied Sciences in Environmental Sanitation, 5 (4), pp. 403-410.

20. Laurinkevičiūtè, A., Kinderytè, L. and Stasiškienè, Ž. (2008). Corporate decisionmaking in furniture industry: Weight of EMA and a Sustainability Balanced Scorecard, Environmental Research, Engineering and Management, 1 (43), pp. 69-79.

21. Savage, D. and Jasch, C. (2005). International Guidance Document on Environmental Management Accounting. New York, NY: International Federation of Accountants (IFAC).

22. Statistics South Africa. (2014). Availiable at: www.statssa.gov.za/?m=2014. Date of access: 7 January 2015.

23. UNDSD (United Nations Division for Sustainable Development). (2001). Environmental management accounting, procedures and principles. New York, NY: United Nations.

24. UNDSD (United Nations Division for Sustainable Development). (2013). Global Sustainable Development Report. Availiable at: http://sustainabledevelopment.un.org/content/ documents/975GSDR\%20Executive $\% 20$ Summary.pdf. Date of access: 14 April 2014.

25. USEPA (United States Environmental Protection Agency) (2014). Pollution prevention: What is EMS? Availiable at: http://www.epa.gov/ems/. Date of access: 12 April 2014.

26. Winston, A. (2011). Lessons Learned from the BP Oil Spill. Available at: http://fas.org/pubs/pir/2011summer/Summer 2011-BPOilSpillHires.pdf. Date of access: 16 August 2014.

27. Živković, S., Takić, L. and Živković, N. (2013). The Improvement of Environmental Performances by Applying ISO 14001 Standards - A Case Study, Chemical Industry \& Chemical Engineering Quarterly, 19 (4), pp. 541-552. 